\title{
Analysis of Livelihoods Security of Three Farmer Communities at Nickel Mining Area
}

\author{
M. I. Mattalitti \\ Faculty of Social and Political Science \\ Muhammadiyah University of Kendari \\ INDONESIA \\ mi_mattalitti@yahoo.co.id
}

\author{
S. R. Ma'mun \\ Faculty of Agriculture \\ Muhammadiyah University of Kendari \\ INDONESIA \\ rahma.mamun@gmail.com
}

\begin{abstract}
- the study aims to investigate the impact of nickel mining activities on the livelihood security of farmers in three farmer communities at South Konawe, and the implications of the policy on their livelihood security. This case study was done in two villages in South Konawe involving three farmer communities. The population of this study was divided into three farmer communities with each focusing on paddy rice, fish and seaweed farming. The sample was drawn using stratified random sampling resulting in 30 samples, with the smallest sample size considerations as widely used in similar studies. This study uses sustainable livelihoods approach as the framework for data analysis. Five indexes were calculated based on the standardized method which consists of economic security, food security, health security, educational security and empowerment security. The result shows that in terms of economic security, seaweed farmer has a higher index compared to the others while fish farmer's index is higher than the others in terms of food security.
\end{abstract} mining

Keywords - livelihood security; farmer community; nickel

\section{INTRODUCTION}

Mining sector has been growing rapidly in South East Sulawesi over the last ten years. The increase lends itself to the government's aim to establish this province as Special Economic Area and due to the province's appointment as one of the centers of development of nickel mining. The shift of economic development towards mining sector has significant contribution to GDP since 2008 until 2012 with $3.3 \%$ increase. On the contrary, the contribution on agricultural sector within the same period decreased by $5.93 \%$, from $36.44 \%$ in 2008 to $30.51 \%$ in 2012 [1]. However, the contribution of this sector to GDP is still the highest among other sectors.

Based on the abovementioned illustration, it is clearly seen that mining sector is very promising in pushing forward the economic growth in South East Sulawesi. However, such a rapid growth has influenced the performance in agriculture sector which is continually decreasing since 2008 despite the fact that most of people in this province, i.e. $40.93 \%$ make this sector as their main source of income compared to those who work in mining sector $(3.24 \%)$. On the other hand, labor transformation from agriculture to mining and many other sectors has been going slowly which affects productivity in South East Sulawesi.

South Konawe Regency is one of the parts in South East Sulawesi where nickel minings are established. Agriculturally, it positions itself as the third biggest rice production in South East Sulawesi with planting area as much as 28,789 hectares and productivity level 4.048 tonnes/hectare. Moreover, its fish pond fishery produces $4,580.78$ tonnes in 2012 [2]. It is also famous as one of the centers of seaweed production in South East Sulawesi.

On local community level, mining industry has influenced the community's livelihood, especially farmers. Some farmer communities in District of Tinanggea, for example, reported to have crop loss within the last two years due to mining activities. Not only paddy field farmers, but also fish pond farmers and seaweed farmers are anxious because of the water they use in their activities is polluted. Besides impacting the farmers' production aspect, mining activities also pollute the air which potentially lead to respiratory infection as reported by some residents. On the infrastructre side, their villages are the main access for the machinery which load the mining products. If this condition is not addressed properly, it will trigger problem between the mining companies and the farmers, which to some extent has existed in Tinanggea District.

There is need to study the impact of mining activities on communities around the area, especially farmers who are immediately affected by the activities. The study is important to gain a better understanding about mining activities in that area and how it affects farmer livelihood. This information can be used to minimize the negative impact of mining activities on communities, as well as designing programs for community development as an implementation of corporate social responsibility by mining companies. To this day, however, less is known what extent the Corporate Social Responsibility done by mining companies increase communities' livelihood.

This study applies sustainable livelihood approach considering that it could give firm understanding about diversity and complexity of community livelihood in a 
certain context [3], as evidenced in some community development programs conducted by international institutions in some developing countries [4] [5]. In the context of change due to nickel mining activities in South Konawe Regency, the impacts on paddy field farming, fish pond, and seaweed farming communities respectively could vary one another, and their livelihood security would be significantly influenced by the extent to what the impact affect their livelihood assets. Therefore, this study aims to: 1) investigate the livelihood security of three communities adversely affected by nickel mining activities; and 2) explore the status of the implications of related policy on the communities' livelihood security.

\section{LITERATURE REVIEW}

\section{A. Sustainable Livelihood Approach}

Concept of livelihood is most widely used when discussing about rural area development and poverty. Chambers dan Conway [6] state that livelihood comprises of ability, assets (saving, sources, claims, and access), and activities needed to survive. Livelihood can be said sustainable when it can overcome and recover the community from stress and shock, maintain and enhance the community's ability and assets, by providing them with sustainable livelihood chance to the next generations. Based on this definition the concept of livelihood is widely developed by some other researchers, for example Schoones [7], Carney [8], and Ellis [9]. Sustainable livelihoods approach (SLA) offers conceptual framework which relates the vulnerability and poverty with environmental resources management [10]. Ellis [9] argues that the significance of SLA is its concern on the relationship between assets and the choices people possess in order to choose alternative activities which could help improve their level of earnings needed for survival.

Assets, which is categorized into five types, i.e. nature, physical, human, finance, and social [7] [8], by Bebbington [11] are not only considered as resources for people to develop their livelihood, but also assets which give them way to power of being and power of doing. In search for comprehensive understanding on the role of the assests, Sen [12] notes three roles, i.e. (a) the direct relationship with human welfare and freedom; (b) the indirect relationship towards economic production; and (c) the indirect role in influencing social change.

From the above elaboration, study on the impact of nickel mining activities towards the farmer communities in South Konawe Regency is considered relevant regarding the information released by some of local publications that mining activities have influenced the community's livelihood assets leading to the fall of their livelihood quality. This study comes with the information on the community's livelihood, especially the farmers, which could be used as the basis for framing the community development programs in the mining areas.

\section{B. Livelihoods Security}

The development of the concept of SLA documented by Hussein [5] and one examples was household livelihoods security (HLS) approach which was used by CARE for community development projects. This approach stemmed from food security perspective but based on the observation that food is only one of the basic primary needs and sufficient food consumption might be sacrificed for the other needs.

CARE defines HLS as sufficient and sustainable access to income and resources for fulfilling the basic needs (including access to sufficient food, clean water, health facilities, school, housing, and time for community participation and social integration) [13]. In short, livelihood security comprises the ability for households to fulfill their basic needs.

The adverse impact of the present nickel mining activities in South Konawe Regency towards the local communities in terms of crop loss or at least the decreasing of the agricultural production could risk their livelihood and prevent them from having safe and better life. Preliminary research in the field have evidenced that the mining activities have made some of the farmer communities vulnerable by decreasing their production to the level that could weaken their livelihood security. This is due to the determinant factor of vulnerability level of household towards risks on income, food, health, and nutrients. The more the resources spent to get food and health service, the higher the household vulnerability level to food and nutrients' vulnerability. Therefore, livelihood will be achieved when the households have secure ownership of or access to tangible or intangible sources and income [14].

The research conducted by CARE was done to formulate community development programs in many developing countries. This approach is holistic by using RRA and PRA methods accompanied by data on household survey on five dimensions of livelihood security, i.e. economic security, food security, health security, educational security, dan empowerment security, which then used to determine livelihood security index [15]. However, the qualitative method could not represent wider communities and cannot be generalized because the sample chosen was not representative of the population as a whole [13]. Similar studies were also conducted by Chinnadurai, et. al. [16] and Rahman and Akter [13] using different analytical framework.

Rahman and Akter [13] measure the livelihood security index using a balanced weighted average approach with some indicators, where each indicator contributes equally to the overall index. The indicators are categorized into different domain representing security areas such as economy, food, nutrients, health, education, etc. Considering that each indicator is measured by different method, the indicators are therefore standardised using "Life Expectancy" approach from Human Development Report adapted with livelihood vulnerability index approach by Hahn, et al. [17].

Similar empirical studies aimed at measuring the livelihood security index have also been conducted in some countries using different indicators. Bhandari and Grant [18], for example, measure the livelihood security index based on the ecological security, while Singh and Hiremath [19] measure the same index using the indicators of economic efficiency, social equality, and ecological security. Based on the aforementioned discussion, this study used the indicators suggested by 
CARE [15], i.e. economic security, food security, health security, educational security, and empowerment security.

\section{METHODOLOGY}

This study was conducted at Wadonggo Village and Lakara Village in South Konawe Regency. This study combined quantitative and qualitative method in which the quantitative method was used to systematically measure the household food security status in order to get representative description of the communities and households in a certain period of time (during the study took place). This study used household survey. Meanwhile, the qualitative method was used to capture the risk process of social, economy, and political interaction which contribute to the farmer households' vulnerability towards food risk. This method was done through observation, Focus Group Discussion, and indepth interview with the key informants.

There were five variables being analyzed in structuring the livelihood security index, i.e. economic security index (4 indicators), food security index (2 indicators), educational security index (2 indicators), health security index (3 indicators), and empowerment security index ( 3 indicators).

Each indicator of livelihood security was measured based on the following equation, as used by Rahman and Akter [13]:

$$
\text { zind }_{j}=\frac{\text { indicator }_{j}-\min j}{\max j-\min j}
$$

where $z$ represents types of indicator and indicator $j$ is respondents' value in the given indicator, while the minimum and maximum values of the indicators are from the same community within which the household belongs.

After each indicator representing livelihood security domains has been calculated, HLS index was constructed based on the averaging standardised indicator as in the following equation.

$$
H L S_{i}=\frac{\sum_{j=1}^{J} z i n d j}{J}
$$

where $\mathbf{J}$ is the number of indicators used to construct the index. In this study, HLS was used to measure each indicator of economic, food, education, health and empowerment security.

\section{RESUlT AND DiSCUSSION}

The following is the general description on the place where this study took place.

\section{A. Setting}

\section{1) Wodonggo Village}

Wodunggu Village, which is located in District of Tinanggea, comprises of four small villages, with 216 households and total 772 population. The primary works of its community are fish pond farmer, paddy field farmer, and plantation farmer. Its primary products are milkfish, shrimp, paddy, and oranges. The fish pond is run with traditional technique by making conduit from the sea. Normally, fish pond can be harvested 3 to 4 times in a year where each hectare yields 3 to 4 tonnes with total price of 40 million rupiahs. The production range of the fish pond is about three months, depending on the distributed seeds. There are also residents who process after-harvest products in form of boneless milkfish. The paddy fields are cultivated with non-irrigation system, depending their watering system on the pouring rain. There are only two public schools, i.e. a kindergarten and an elementary school. Youth association and farmer association (both fish pond farmer and paddy field farmer) are the types of its community-based association. As much as 90 households are listed in the rice-for-poor program, but in fact the rice is distributed to all households with no exception due to complaints from some of the residents. Most of the community use artesian well in fulfilling their need on clean water.

In 2013, there was a dispute with the mining company due to mining activities which adversely affected the community's work. Based on the interview, the effect of the mining activities to the community was the result of the activities of ore transportation from the exploitation field to the stock field. In general, the fish pond farmers reported that they were affected in terms of air pollution-dusts were everywhere, noise pollutionrumbling sound and the movement of the machinery, and too much lights at night. Especially for the fish ponds located adjacent to the stock field, they got direct impact in form of mud during the rain. The pollution had caused problem to the community's fish pond production, such (1) smaller harvested fish and late harvesting season (1) which even took seven months instead of the three-month period. The companies compensated the land owner Rp 100,000 per hectare per shipment, while those who do not own land were compensated Rp 200,000 per household per shipment. Apart from that, the companies also donated 30 million rupiahs for the mosque building.

Based on the interview, the community basically did not get any direct nor indirect significant benefit of the mining activities in their village. The benefit was only felt by two residents who were recruited as the workers in the mining company. They worked as machinery supervisor and security respectively but were fired once the mining was closed. Ever since the mining activities (2) were stopped in early 2014, the community acknowledged that there were significant changes in their production which back to normal as before the mining activities occupied their village.

\section{2) Lakara Village}

Lakara Village is located in District of Palangga in South Konawe. There are 780 population with 220 households. Compared to Wadonggo Village, access to clean water is limited in this village. Most of the residents fulfill their need for clean water from artesian well.

The main source of income in this village are farmer and fisherman. Its primary products are cashew nut, tamarind, mango, cacao, teak wood, and seaweed. On average, the fishermen own boat and traditional fishing tools such as panja' (basket fish trap), fishing rod, bubu' (portable shrimp/fish trap), and fishing net. The fishermen's earnings were about Rp 200,000 per day 
(with net earnings about Rp 40,000 per day). Some farmers may harvest their seaweed four times in a year. The women are involved in blue crab production with $\mathrm{Rp}$ 1,000 pay per kilogram or reaching about Rp 150,000 per week.

Due to the mining activities, sea water pollution which caused harm to seaweed culture and smaller catching area to the fishermen were the direct impact to the community. The pollution was caused by ore spill on the sea when the ships were loaded up. Similar compensation scheme with the one in Wadonggo Village also applied in this village.

\section{B. Findings and Discussion}

The findings and analysis of this study will be discussed under five indicators, i.e. economic, food, education, health, empowerment. It is then ended with the implication of policy on livelihoods security.

\section{1) Economic Indicator}

The economic indicator measurement does not involve the width of the farming area and the productivity sub-components due to difference in farming types requiring different size in order to get maximum result. Based on the economic security index measurement, the highest index is shown by the seaweed farming.

TABLE I. ECONOMIC SECURITY INDEX

\begin{tabular}{|l|c|c|c|}
\hline \multirow{2}{*}{$\begin{array}{c}\text { Indicator } \\
\text { Components }\end{array}$} & \multicolumn{3}{|c|}{ Economic Indicator } \\
\cline { 2 - 4 } & $\begin{array}{c}\text { Paddy Field } \\
\text { Farming }\end{array}$ & $\begin{array}{c}\text { Fish Pond } \\
\text { Farming }\end{array}$ & $\begin{array}{c}\text { Seaweed } \\
\text { Farming }\end{array}$ \\
\hline Income & 0.18 & 0.26 & 0.14 \\
\hline Side income & 0.15 & 0.04 & 0.65 \\
\hline Saving & 0.66 & 0.86 & 0.96 \\
\hline Credit usage & 0.13 & 0.03 & 0.52 \\
\hline Index & 0.28 & 0.30 & 0.57 \\
\hline
\end{tabular}

Based on the Table I, paddy field farming has lower economic security index than fish pond farming and seaweed farming, where the income of the paddy field farmers are the lowest. Regarding the distribution ownership of the cultivating field, about $47 \%$ of the respondents have less than 1 hectare, $15 \%$ have between 1-2 hectares, and only $1 \%$ of them has 3 hectares. In terms of seaweed culture, most respondents only own less than 1 hectare. Fish pond farmers, on the contrary, are on the highest ownership rate. Only $11 \%$ of the respondents' own less than 2 hectares, $15 \%$ own between 2-3 hectares, and $10 \%$ have more than 3 hectares. Therefore, the wider ownership of the fish pond farming contributes to the bigger income compared to the other works. The seaweed farmers' side-income which are bigger than the other two farmer communities might help the economic security of the community in general.

The low index shown by the farming sub-indicator indicates the high range of the respondents' household income and proofs the range income variety. Although the farming income reveal that fish pond farming contribute to bigger seasonal income compared to the other two famings, but in general, the highest economic security index applies to seaweed farming. The highest index shown in the seaweed farmers' side-income is because on average the respondents are also fishermen with income about $\mathrm{Rp} 800,000$ to $\mathrm{Rp} 2,000,000$ per month.

Based on in-depth interview, the seaweed farmers were the most adversely affected by the nickel mining activities. It is because the oil waste and the ore spill polluted the surrounding coast causing crop loss in the seaweed culture. The impact on the paddy field farmers and the fish pond farmers were the decrease of production as previously mentioned, but not as severe as the impact on the seaweed farmers. Moreover, the pollution stopped the women in Coastal Lakara Village getting side income from seeking blue crab.

\section{2) Food Indicator}

The food indicator in this study is the meal time in a day with the variety of food measured by the amount of food consumed within the last 24 hours, and the food crisis experience within the last one year. Based on the interview with the household mothers, there are 10 groups of food consumed by the households within the last 24 hours, i.e. cereal, edible roots, fish, green vegetable, fruit, bread, meat, noodle, beverage, and snack. However, only three of the groups, i.e. rice, vegetable, and fish, were consumed by $50 \%$ of the respondents. As for the experience on food crisis subcomponent, positive response (ever been through such crisis) reveals low food security with 0 index value. On the contrary, negative response (never been through food crisis within a year) shows high food security rate with 1 index value. Compared to paddy field farming and seaweed farming, the food security index of fish pond farming is bigger than the other communities. It is shown by some of the respondents' average meal time 5 times a day ( 3 times meal and 2 times snack), with more varieties than the other farming communities, which indicate different index for each sub-components but revealing similar security index value.

TABLE II. FOOD SECURITY INDEX

\begin{tabular}{|l|c|c|c|}
\hline \multirow{2}{*}{ Indicator Components } & \multicolumn{3}{|c|}{ Food Indicator } \\
\cline { 2 - 4 } & $\begin{array}{c}\text { Paddy Field } \\
\text { Farming }\end{array}$ & $\begin{array}{c}\text { Fish Pond } \\
\text { Farming }\end{array}$ & $\begin{array}{c}\text { Seaweed } \\
\text { Farming }\end{array}$ \\
\hline $\begin{array}{l}\text { Meal time frequency in } \\
\text { a day }\end{array}$ & 0.27 & 0.35 & 0.23 \\
\hline $\begin{array}{l}\text { DDI (Dietary Diversity } \\
\text { Index) }\end{array}$ & 0.13 & 0.20 & 0.17 \\
\hline Food crisis experience & 1.00 & 1.00 & 1.00 \\
\hline Index & 0.20 & 0.28 & 0.20 \\
\hline
\end{tabular}

\section{3) Education Indicator}

The education indicator is measured based on the household fathers' education and the household mothers' education sub-indicators. Based on the survey it is found out that in general, educational security index is better on the seaweed farmer households. Based on Table III, the participation rate of female in education is better than male. It is measured by the presentation of female in every level of education out of the total population of the household mothers in each farming community resulting in only $8 \%$ of the fish pond farmer with no educational background. Meanwhile, the male presentation, which is measured by the households' education, reveals those with no educational background as much as $6 \%, 4 \%$, and 
$7 \%$ for paddy field farmer, fish pond farmer, and seaweed farmer respectively. However, overall education rate of both household fathers and mothers is considered low, since it is still dominated by $44 \%$ to $77 \%$ elementary level graduates.

TABLE III. EDUCATIONAL SECURITY INDEX

\begin{tabular}{|l|c|c|c|}
\hline \multirow{2}{*}{$\begin{array}{c}\text { Indicator } \\
\text { Components }\end{array}$} & \multicolumn{3}{|c|}{ Education Indicator } \\
\cline { 2 - 4 } & $\begin{array}{c}\text { Paddy Field } \\
\text { Farming }\end{array}$ & $\begin{array}{c}\text { Fish Pond } \\
\text { Farming }\end{array}$ & $\begin{array}{c}\text { Seaweed } \\
\text { Farming }\end{array}$ \\
\hline Household education & 0.47 & 0.44 & 0.68 \\
\hline Women education & 0.58 & 0.53 & 0.60 \\
\hline Index & 0.58 & 0.49 & 0.64 \\
\hline
\end{tabular}

\section{4) Health Indicator}

The health security indicator is measured based on the amount of family member with chronic disease within the last one month, the amount of family member who cannot work due to sickness, and the amount of family member with diarrhoea within the last one month subcomponents. Regarding that the trace of three subcomponents represents the decrease of health security in the certain households, higher number (1) is given to negative response or no report of incident at all, and lower number (0) is given to positive response of each sub-component. The result of the measurement is illustrated in Table IV which states that all three farmer communities have good health security with minimum incidents experienced by the family member of the respondents.

TABLE IV. HEALTH SECURITY INDEX

\begin{tabular}{|l|c|c|c|}
\hline \multirow{2}{*}{\begin{tabular}{c}
\multirow{2}{*}{$\begin{array}{c}\text { Indicator } \\
\text { Components }\end{array}$} \\
\cline { 2 - 4 }
\end{tabular}} & $\begin{array}{c}\text { Paddy Field } \\
\text { Farming }\end{array}$ & $\begin{array}{c}\text { Fish Pond } \\
\text { Farming }\end{array}$ & $\begin{array}{c}\text { Seaweed } \\
\text { Farming }\end{array}$ \\
\hline Chronic disease & 0.91 & 0.96 & 0.96 \\
\hline $\begin{array}{l}\text { Not working due } \\
\text { to sickness }\end{array}$ & 1.00 & 0.96 & 1.00 \\
\hline Diarrhoea & 0.97 & 1.00 & 1.00 \\
\hline Index & 0.96 & 0.97 & 0.99 \\
\hline
\end{tabular}

\section{5) Empowerment Indicator}

Community participation is the main factor in determining the community's development process since without community's participation and empowerment, development goal cannot be reached [20]. In this study, the empowerment security index is measured based on the presentation of respondents' involvement in the village planning and in the farmer association ranging from 0 to 100 .

Findings on survey reveal that the low empowerment security index indicates the low participation rate of the community in the village planning and other development activities. Out of the three farming communities, the seaweed farmer community shows $0 \%$ in each of measured empowerment indicator.

\section{6) Livelihoods Security and Policy Implication}

South Konawe Regency is one of the centers of mining activities in South East Sulawesi. Since 2008 nickel mining has been one of the primary sources of governmental revenue. However, when the study was conducted, the mining activities were temporarily stopped because the regulation issued by the government prohibits the export of unprocessed product such as ore. Therefore, the information on the impact of the mining activities towards the community's livelihood was gathered through historical data based on in-depth interview with some key informants and Focused Group Discussion.

Based on the interview and the discussion, it is revealed that the previous nickel mining activities had effect on the decreasing paddy production. The transportation process of the ore to the loading port which passed by the paddy field areas caused the plants covered by thick dust making them grew in severe condition. Some of the fish pond farmers complained that the muddy water in the conduit, due to the mining activities in the upstream, had adversely affected their production though not as severe as those in paddy field. The adverse effect of the mining activities was heavily experienced by the seaweed farmers because the ore spill and oil waste polluted the coastal area around the loading port where they cultivated their seaweed. Also, the crashing sea waves caused by the loading ship took part in destroying the seaweed culture. Some of the farmers even had to move to farther location so that they could still keep cultivating their seaweed. As regards these conditions, of the three farmer communities, seaweed culture tends to at most risk. Therefore, the vulnerability experienced by the communities due to the mining activities should be highly considered.

Among the three farmer communities, their health security index is the highest, while empowerment security is the lowest, indexing 0 on the seaweed farmers. The low rate of community participation, especially the seaweed farmer community, was also confirmed thorugh in-depth interview, that they acknowledged of having no organized seaweed farmer association. Empowerment security index indicating the community participation rate measured by their participation in the village planning and membership in farmer association should be considered by the stakeholders. In line with Mosher [21], the farmer activities involved in such association is one of the requirements in the success of agricultural development. In a similar vein, Wahyuni [22] argues that one of the social problems preventing the success of the technology adoption on the farmer level is lack of institutional role, in this case farmer association. On the other side, the low rate of farmer participation in the village planning process could result in their interests not being represented and covered in the village development programs. Regarding with the prospective nickel mining activities in the future after the establishment of smelter in this regency, the funding from the companies' corporate social responsibility and community development could be more appropriate and targeted to the right community and could be more sustainable when the community participation in the village program planning is better. 


\section{CONCLUSION}

This study aimed at analyzing the status of livelihood security of three farmer communities in the area of nickel mining at South Konawe Regency and its implication on the related policy. The findings revealed that in general the communities' health security index is high, while the empowerment security index, on the contrary, is very low, even reaching 0 for the seaweed farmer community. This should be of our great concern because the community involvement, individually or collectively, is one of the key success factor in the agricultural development which will ease the adoption of technology in order to improve their production and welfare.

\section{ACKNOWLEDGMENT}

This research was funded by Directorate General of Higher Education, Ministry of Education and Culture in 2014.

\section{REFERENCES}

[1] Badan Pusat Statistik, 2013(a). Produk Domestik Bruto Sulawesi Tenggara. Available http://sultra.bps. go.id/web/frontend/Subjek/view/id/52\#subjekVie wTab3\%7Caccordion-daftar-subjek2, accessed on 25 September 2015

[2] Badan Pusat Statistik, 2013(b). Sulawesi Tenggara dalam Angka 2013. Badan Pusat Statistik Sulawesi Tenggara.

[3] K. Brock, Implementing Sustainable Livelihoods Framework for Policy-Directed Research: Reflection on Practice in Mali. IDS Working Paper No. 90. Brigthon: IDS, 1999.

[4] C. Ashley and D. Carney, Sustainable Livelihoods: Lessons from Early Experience. London: DFID, 1999.

[5] K. Hussein, Livelihoods Approaches Compared: A Multi-Agency Review of Current Practice. UK: Department for International Development and ODI, 2002.

[6] R. Chambers and R. Conway, Sustainable Rural Livelihoods: Practical Concepts for the $21^{\text {st }}$ Century. IDS Discussion Paper No. 296. Brigthon: IDS, 1992.

[7] I. Schoones, Sustainable Rural Livelihoods: A framework for Analysis. IDS Working Paper No. 72. Brigthon: IDS, 1998.

[8] D. Carney, "Implementing the sustainable livelihoods approach", in Sustainable Rural Livelihoods: What Contribution can we Make?, D. Carney, Ed. London: DFID, 1998.

[9] F. Ellis, "Rural livelihoods and poverty reduction strategies in four African countries", The Journal of Development Studies, vol. 40, no. 4 , pp. 1-30, 2000.
[10] S. Seshia and I. Schoones, Understanding Access to Seeds and Plant Genetic Resources: What can a Livelihoods Perspective Offer? LSP Working Paper 6. Rome: Food and Agriculture Organization, 2003.

[11] A. Bebbington, "Capital and capabilities: a framework for analyzing peasant viability, rural livelihoods and poverty", World Development vol. 27. no. 12, pp. 2021-2044, 1999.

[12] A. Sen, "Editorial: Human capital and human capability", World Development, vol. 25, no. 12, pp. 1959-1961, 1997.

[13] S. Rahman and S. Akter, Determinant of Livelihood Security in Poor Settlement in Bangladesh. NAF International Working Paper Series 10/01, 2012. Available at http://economia.unipv.it/naf/, accessed on 12 December 2013.

[14] T. R. Frankenberger, K. Luther, J. Becht, and M. K. McCaston, CARE household livelihood security assessment: A toolkit for practitioners, Prepared for the PHLS Unit by TANGO International Inc. Tucson, Arizona: TANGO International Inc., 2002.

[15] M. Lindenberg, "Measuring household livelihood security at the family and community level in the developing world", World Development, vol. 30, no. 2, pp. 301-318, 2002.

[16] M. Chinnadurai, N. Tulkarni and B. Swaminathan, "Livelihood security status in the dryland areas of Belaary District, Karnataka", International Journal of Science and Nature, vol. 3, no. 4, pp. 857-862, 2012.

[17] M. B. Hahn, A. M. Reader, and S. O. Foster, "The livelihood vulnerability index: A pragmatic approach to assessing a climate variability and change: A case study in Mozambique", Global Environmental Change, vol. 19, pp. 74-88, 2009.

[18] B. S. Bhandari and M. Grant, "Analysis of livelihood security: A case study in the Kali-Khola watershed Nepal", Journal of Environmental Management, vol. 85, pp. 17-26, 2007.

[19] P. K. Singh and B. N. Hiremath, "Sustainable livelihood security index in a developing country: A tool for development planning", Ecology Indicators, vol. 10, pp. 442-451, 2010.

[20] A. Samah, Asnarulkhadi and Farhorz Aref, "The theoritical and conceptual framework and application of community empowerment and participation in process of community development in Malaysia”, Journal of American Science, vol. 7, no. 2, pp. 186-195, 2011.

[21] A. T. Mosher, Menggerakkan dan Membangun Pertanian: SyaratSyarat Pokok Pembangunan dan Modernisasi . Jakarta: CV Yasaguna, 1987.

[22] S. Wahyuni, "Kinerja kelompok tani dalam sistem usaha tani padi dan metode pemberdayaannya", Jurnal Litbang Pertanian, vol. 22, no. 1, pp. 1-8, 2003. 